\title{
Article \\ The Effect of Artificial Intelligence (AI) on the Quality and Interpretation of Financial Statements in the Hotels Classifiedin the AQABA Special Economic Zone (ASEZA)
}

\author{
Mousa Mohammad Abdullah Saleh ${ }^{1}$, Omar A. A. Jawabreh ${ }^{2 *}$, Nawaf N. Hamadneh ${ }^{3}$, Muhammad Tahir ${ }^{4}$, Rania \\ Al Omari ${ }^{5}$ and Nazem Shniekat ${ }^{1}$ \\ 1 Department of Financial and Administrative Sciences, Al-Balqa Applied University, Jordan; \\ dr.mousasaleh@bau.edu.jo, Nazem1989@bau.edu.jo \\ 2 Department of Hotel Management, Faculty of Tourism and Hospitality, The University of Jordan; \\ o.jawabreh@ju.edu.jo \\ 3 Department of Basic Sciences, College of Science and Theoretical Studies, Saudi Electronic University, \\ Riyadh 11673, Saudi Arabia; nhamadneh@seu.edu.sa \\ 4 College of Computing and Informatics, Saudi Electronic University, Riyadh, Saudi Arabia; \\ m.tahir@seu.edu.sa \\ 5 Department of Accounting, Faculty of Business and Finance, University of Jordan, Jordan; \\ r.omari@ju.edu.jo
}

\begin{abstract}
The study aims to examine the effects of artificial intelligence (AI) on the consistency and analysis of financial statements in hotels in the Aqaba Special Economic Zone (ASEZA) in Aqaba, Jordan. This research is an exploratory, empirical study, which uses the methodology of data collection and interpretation to draw conclusions. The researchers used the arithmetic mean, standard deviation, T-test and ANOVA test to calculate the degree of significance of the study questions. The findings of a basic linear regression study of the impact of AI

implemented in Jordanian hotels on the integration of accounting information systems and the association between $\mathrm{AI}$ and the integration of accounting information systems

$(\mathrm{R}=59.6 \%)$ also indicate that the fixed limit value amounted to (2.060) and the value of (Beta) for $\mathrm{t}$.
\end{abstract}

Keywords: Artificial intelligence; Accounting systems integration; Accounting systems accuracy; financial statements; Aqaba Special Economic Zone

\section{Introduction}

AI allows them to make the most possible use of the tools avail- able and offers accountants time and energy to evaluate, perceive data and represent the true meaning of the business and its clients. According to the annual Sage Survey, "The Practice of Now" almost $58 \%$ of accountants strongly agree that AI will boost the effi- ciency of their businesses in the future. If we progress in the implementation of AI, there are three fields that are especially useful for carrying out accounting activities, such as continual auditing, disguised accounting, and a detailed and in-depth view [1]. On the other hand, AI helps companies immediately recognize and admit all ongoing activities, reconcile and audit accounts on an ongoing basis, and make necessary adjustments, when needed, such as organizing benefits throughout the month. This gives companies an opportunity to lighten account loads at the end of the month. Financial professionals will also benefit from the advantages of integrating $\mathrm{AI}$ in the accounting processes over the coming months and years. The science of accounting is closely related to technology, so companies have begun to 
improve their competitive position by making many technology-related decisions such as the use of cloud computing and ERP systems.

Hotel activity is one of the most important economic activities whose success depends on the success of its management, it knows the essence of the administrative organization, the usefulness of the human aspect, the accuracy of the accounting method utilized and the evidence it produces [2].

Ascott, the world's largest operator of hotel apartments that is based in Dubai, has revealed that it has conducted advanced tests in the field of AI in order to improve the effectiveness of operational processes within the hospitality sector and provide better services to customers [3, 4].

This paper clarifies how AI interacts dynamically with accounting systems to help hotel managers deliver high-quality accounting details by reducing information threats. Despite the many forms of studies suggested utilizing artificial intelligence in accounting and auditing, none of them explicitly discusses how to minimize knowledge losses when using AI. Firms benefit from analysis to minimize many of the costs and damages that arise from failure to deliver accurate accounting records, and to help management make smarter choices and enhance facility efficiency.

\section{Literature Review}

The development in information technology (IT) has shown a significant role to play in the area of accounting. With the advent of Enterprise Resource Planning (ERP) in the 1990s, several companies have started applying IT management accounting to retain their competitive edge. The volume of data and knowledge needed has gradually grown with time, with the exponential growth of computer technology, business intelligence and analytics (BI\&A). Recent technical advancements have once again diverted focus to an important form of information science, AI [5-7]. This is a sophisticated method of market research. This word applies to the digital representation of human thought.

In 2017, the Institute of Chartered Accountants of England and Wales (ICAEW) published an article entitled "AI and the Future of Accounting" which dealt with the application and use of this technology in accounting and auditing. In it, it was mentioned that $\mathrm{AI}$ will radically change the accounting profession, which must prepare for this stage. The relationship between the concept of AI with the requirements of accounting business and the increasing uses of electronic transactions, especially in the hotel sector, has become predominant in the nature of electronic work in most of the dealings and transactions with individuals and companies in various hotels in a competitive manner [8,9].

Dan.W. Paterson described AI: "It is a branch of computer science that is associated with researching the formation of computer systems that display certain types of knowledge. These systems have the potential to make very valuable assumptions regarding the issue that has been identified. These systems may often understand natural languages; understand living experiences and other abilities that require intelligence as they are applied [10].

Today, hotel activity is considered one of the most important \& developed economic activities in all parts of the world, and the hotel industry is the backbone on which tourism is based [11]. Perhaps the nature of the hotel service, its diversity and the advancement of its level lead us to the desired goal, which is the advancement of the level of the hotel industry. The success of hotel establishments depends on the success of their management.

The level to which they consider the essence of the administrative organization, the usefulness of the human factor, the consistency of the accounting method used and the extent to which the details generated by the system was used. The rules and principles that govern the accounting organization process in hotel establishments are the same 
as the rules, principles and policies of the accounting organization in general, and the difference is limited to the field of implementation [12]. This requires that the accounting system reflects the characteristics and features of the field of implementation. In general, the basic objectives of the accounting organization for any activity must ultimately revolve around the necessity of recording that activity's transaction and financial events, in a manner that enables the outcome of the activity's work to be determined and measured in the form of net profit or net loss. The core of the accounting organization for any activity must ultimately revolve around the necessity of recording that activity's financial transactions and events, in a way that enables the outcome of the activities work to be determined and measured in the form of net profit or net loss, as well as the financial position of the activity at the end of a certain period. In addition to the necessity to preserve the assets and properties of the activity and to provide oversight and protection from all kinds of fraud, theft, manipulation or loss, in addition to providing the necessary information for planning, control and decision-making purposes $[8,13]$. Therefore, the accounting system must be appropriate for the considerations of many of the hotel's activity, the most important the appropriateness and compatibility with the nature and characteristics of the hotel activity, while not neglecting two factors, namely accuracy and speed in producing information. Also, the ability to produce all kinds of data and information in a timely manner for the purposes of: planning, control and unity of decisions, whether for the hotel management or for the supervisory and external bodies related to the activity. The flexibility of the system that enables it to accommodate seasonal changes in the size of the hotel activity, without needing to redesign the system in the event of changes whether increase or decrease. The ability to meet the needs of the hotel activity in its diversity, i.e. overnight service activities for inmates, commercial activities such as buying foodstuffs, various selling stores, industrial activities such as preparing and serving meals, and agricultural activities such as owning vegetable, fruit, poultry and livestock farms. So the accounting system is able to track and prove these various operations, and determine the cost and revenue of each activity or function separately, and giving importance to the statistical data of the movement of hotel's inmates, and providing appropriate information about them along with the financial statements, due to the importance of that data in planning and making decisions [14].

\section{Efficiency and effectiveness of artificial intelligence systems}

AI technologies have made a revolution in the field of information technology, since AI is a sub-field of computer science; it includes creating smart devices and programs that work and interact like humans [15]. It is "a name commonly used to refer to the field of science that aims to provide machines with the ability to perform functions such as logic, planning, learning and perception [1,16-21]. Therefore, the meaning of AI can be expanded to include a

set of different and intertwined abilities, such as creativity, emotional knowledge and self-awareness [22].

The ability of AI to accommodate a more important data flow into accounting records will expand accountants' capabilities to broaden predictive consulting services to other areas of business. For example, if a manufacturer notices a rise in supplier costs, an accountant who is equipped with AI technologies can forecast the impact on the business in the near future. Accountants can now suggest the most appropriate action to address a potential shortfall before it causes problems. So, while we watch the movement of an express train crossing the station, sophisticated train services can now alert passengers to a problem in the schedule before boarding the train, and suggest other routes or alternative modes of transportation [23].

Therefore, the AI system has a great impact on many applied sciences, such as the science of accounting [24-30]. In the field of data processing, AI has led to a wide change in the nature of accounting work in general and in its procedural nature in particular. Ready-made software in accounting can record, classify and summa- 
rize information without the need for human intervention. As for the control function, which is one of the most important accounting functions, it has become possible through advanced manufacturing systems for the machine to exercise self-control through the concept of AI, which has caused financial accounting and cost account-

ing lose their traditional functions [31,32]. These changes, in addition to other changes in the business environment cast a shadow on management accounting itself, which led to the emergence of new techniques that help provide better information to managers so that they can manage their facilities. Although it emerged as a response and adaptation to specific circumstances, it was able to achieve a qualitative development in the nature of the information provided to management.

The first hypothesis: Artificial intelligence systems in Jordanian hotels are not efficient and effective.

\section{Integration and interdependence of the accounting system}

The accounting information system is one of the tools of the institutional finance system, which involves systems for gathering, classifying, sorting, interpreting and distributing financial and quantitative information to decision-makers through computers [33].

In addition, the information structures consist of a set of integrated components with each other and with the external world, since each component relies on the other to accomplish the objectives followed by the accounting method. It is thus a network of interrelated activities controlled by sound concepts and laws, which are prepared in an organized fashion with the goal of delivering details and knowledge to the decisionmaker in a manner that is suitable to his needs $[34,35]$. As a result of advances in the area of information and technology, businesses have been able to computerize their information processes, particularly accounting information systems, thanks to substantial technical changes. Consequently, accountants must learn the expertise required for the usage of computerized applications. The usage of computerized accounting software systems has created ways for businesses to conduct accounting functions more accurately and efficiently with information systems. These systems save time and cost, as the use of information technology to perform accounting functions is an incentive for companies to transition into paperless business. Firms that introduce a development method will implement it more efficiently when utilizing computerized processes.

The second hypothesis: there is no statistically important impact on the performance and efficacy of artificial intelligence on the incorporation and interdependence of the accounting method in Jordanian hotels at the stage of importance $(\alpha \leq 0.05)$

\section{The accuracy of the accounting system}

The accounting tools currently used do not provide accurate information and even exclude basic indicators for evaluating the performance of the production process, leading to ill-considered decisions by managers [36]. So managers wanted new accounting tools that provide accurate information about costs that manufacturing activities incur quickly [37]. Such as the difference between actual and projected manufacturing cost. Costs can be reduced more easily through the process of identifying, managing and controlling costs known as cost accounting. This type of accounting is used for managing accounting purposes, which means that the results obtained are aimed at facilitating the decision-making process of managers to ensure informed decisions are made [38,39]. Accounting tools should include accurate calculations to increase the quality of the information obtainedbefore focusing on reducing variances and increasing the accuracy of the calculated results.

Thus, the most important characteristics of information quality are accuracy and completeness, and the concept of accuracy has great similarities with the concept of truthful representation used by (IASB) 2010, [40]. The accuracy of the decisions that 
are made, whether by internal or external users, is strongly affected by the quality of accounting information, and just as the quality of this information helps reduce the state of uncertainty by users [41-44]. The accounting information technology that is used within the organization has the ability to cancel the limitations of traditional accounting, and to ensure the security of accounting information in order not to be penetrated by the accounting systems of any organization.As well as working to update and monitor these programs constantly in order to increase the security of these systems $[45,46]$.

The implementation of these goals together is a basic requirement for an effective and accurate accounting system, if the first goal referred to among the other ones is related to the technical aspect of the accounting department, the rest of all the goals can be easily prepared by the hotel.

The third hypothesis:There is no statistically significant effect at the level of $(\alpha \leq 0.05)$ for the efficiency of the effectiveness of artificial intelligence on the accuracy of the accounting system in Jordanian hotels.

\section{Quality of interpretation and presentation of accounting information}

The general philosophy extracted from the legislation was focused on the relationship between a good corporate governance process, a robust internal management structure and a high degree of auditor independence to provide accurate accounting details. The concern emerges as to how information technology, through artificial intelligence, may assist and facilitate decision-making relevant to the SOX mandates, as there are two forms of trials, one before the SOX Act and the other after the implementation of the Act $[47,48]$. Studies have demonstrated the degree of the importance of businesses in releasing actual financial records and have recommended certain intelligence mechanisms to assist external auditors in their decision-making processes in order to assess whether or not these reports are accurate. AI can allow administrators

to generate knowledge that is more accurate for consumers. This could be accomplished through avoiding and addressing complicated problems by AI, such as weakness of the internal cash management mechanism, inventory, etc.

The importance of accounting information has been known and used by humans since a long time, yet no era has seen such importance of information to the extent that some concepts spread to give the current era the character of information such as (the information age, the information revolution, artificial intelligence) [49-51]. As it represents $\mathrm{AI}$ and consists of "experience systems" and "network structures". Information has become an indispensable element in the production process of economic units.

The preparation of this information in accordance with quality and comprehensiveness standards is so important that it can be relied upon in a way that reflects the confidence of stakeholders in the establishment and its management.

The fourth hypothesis: There is no statistically significant impact at the level of significance $(\alpha \leq 0.05)$ for the efficiency and effectiveness of artificial intelligence on the quality and interpretation of financial statements in Jordanian hotels.

\section{Methodology}

\subsection{Study Model}

The idea of the study model progressed through reviewing the [49] study, in which a model was designed that focuses on the effectiveness of internal control over financial reports, as the stronger the internal control system, the more reliable and high-quality financial information and reports will be [52]. listed ten accounting topics that can be combined with AI, most notably the prediction of default and bankruptcy, management fraud detection, and machine learning techniques to automatically characterize fraud and AI in marketing [53]. Presented a practical model for applying AI to produce high-quality accounting information by mitigating weak internal controls in nearly every industry. Accordingly, through the study, an attempt was made to link 
AI directly with accounting systems, and how improved those systems are by working on the integration and interdependence of these systems, increasing the accuracy of their outputs and improving the quality of the accounting information issued by them.

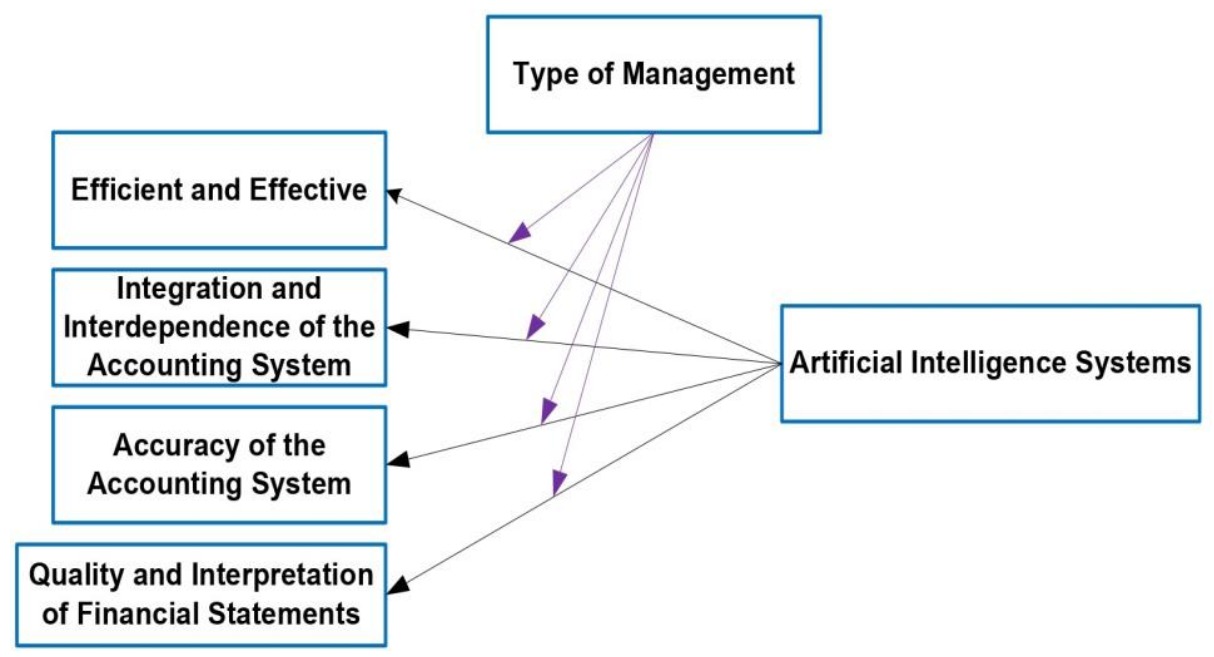

Figure 1. The model of the study

\subsection{Study Tool}

The researchers used the questionnaire to find out the opinions of the sample of the study, after having viewed the theoretical literature related to the subject of the study, whether it was provided in references or in scientific journals and theses. The questionnaire consisted of the following parts: The first part: concerned with the demographic factors of the study sample. The second part: concerned with measuring the efficiency and effectiveness of AI in hotels. The questionnaire consisted of Phrases from (1) to (12): are concerned with measuring the availability of procedures for applying AI systems in hotels, and means to assist in providing services to customers. Phrases (13) to (20): are concerned with measuring the integration of accounting systems in hotels Phrases (21) to (26): are concerned with measuring the accuracy of accounting systems in hotels Phrases (27) to (32): are concerned with measuring the quality of hotel accounting systems' reports. Regarding data analysis and hypothesis testing, the study adopted a descriptive data analysis method based on the five-dimensional Likert scale, as well as the simple linear regression analysis to prove the study hypotheses. Reliability and stability of the measuring instrument: In order to verify the validity and reliability of the measuring instrument, the questionnaire was presented to a number of arbitrators, and their comments were taken into consideration when preparing the final wording of the questionnaire statements. The stability of the scale was verified using the Cronbach's Alpha analysis. The ratio of the stability factor of the resolution as one unit was $683 \%$. These percentages exceed the statistically acceptable percentage of $60 \%$, which indicates a relationship of consistency and coherence between the questionnaire statements. 
Table 1. Measuring the stability of the measuring instrument.

\begin{tabular}{ll}
\hline Cronbach's Alpha & Variant \\
\hline$\% 741$ & Accounting systems integration \\
$\% 795$ & Accounting systems accuracy \\
$\% 529$ & The quality of accounting systems reports \\
$\% 411$ & Type of management \\
$\% 683$ & The whole questionnaire \\
\hline
\end{tabular}

Analyzing results and testing hypotheses First: Characteristics of the study sample

Table 2. The demographic factors of the study sample.

\begin{tabular}{|c|c|c|c|c|c|c|c|c|c|c|}
\hline \multirow{3}{*}{ Age } & \multicolumn{2}{|c|}{25 years or less } & \multicolumn{2}{|c|}{$26-30$} & \multicolumn{2}{|c|}{$31-40$} & \multicolumn{2}{|c|}{$41-50$} & \multicolumn{2}{|c|}{$51-60$} \\
\hline & No. & $\%$ & No. & $\%$ & No. & $\%$ & No. & $\%$ & No. & $\%$ \\
\hline & 60 & 34.9 & 31 & 18 & 57 & 8.7 & 15 & 8.7 & 9 & 5.2 \\
\hline \multirow{3}{*}{ Educational Qualification } & \multicolumn{2}{|c|}{ High School } & \multicolumn{2}{|c|}{ Diploma } & \multicolumn{2}{|c|}{ BA. } & \multicolumn{2}{|c|}{ MA. } & \multicolumn{2}{|c|}{ PhD. } \\
\hline & No. & $\%$ & No. & $\%$ & No. & $\%$ & No. & $\%$ & No. & $\%$ \\
\hline & 4 & 2.3 & 34 & 19.8 & 80 & 46.5 & 46 & 26.7 & 8 & 47 \\
\hline \multirow[t]{3}{*}{ Major } & \multicolumn{2}{|c|}{ Accounting } & \multicolumn{2}{|c|}{$\begin{array}{c}\text { Business } \\
\text { Administration }\end{array}$} & \multicolumn{2}{|c|}{$\begin{array}{c}\text { Finance and } \\
\text { Banking }\end{array}$} & \multicolumn{2}{|c|}{ Others } & & \\
\hline & No. & $\%$ & No. & $\%$ & No. & $\%$ & No. & $\%$ & & \\
\hline & 140 & 81.4 & 19 & 11 & 2 & 1.2 & 11 & 6.4 & & \\
\hline \multirow{3}{*}{ Years of Work Experience } & \multicolumn{2}{|c|}{5 years or less } & \multicolumn{2}{|c|}{$6-10$} & \multicolumn{2}{|c|}{ 11-15 } & \multicolumn{2}{|c|}{16 or more } & & \\
\hline & No. & $\%$ & No. & $\%$ & No. & $\%$ & No. & $\%$ & & \\
\hline & 87 & 50.6 & 49 & 28.5 & 20 & 11.6 & 16 & 9.3 & & \\
\hline \multirow[t]{3}{*}{ Management Type } & \multicolumn{2}{|c|}{ Independent } & \multicolumn{2}{|c|}{$\begin{array}{l}\text { Corporate } \\
\text { contracts }\end{array}$} & \multicolumn{2}{|c|}{ Chain } & & & & \\
\hline & No. & $\%$ & No. & $\%$ & No. & $\%$ & & & & \\
\hline & 89 & 51.7 & 32 & 18.6 & 51 & 29.7 & & & & \\
\hline \multirow{3}{*}{ Gender (Sex) } & \multicolumn{2}{|c|}{ Male } & \multicolumn{2}{|c|}{ Female } & & & & & & \\
\hline & No. & $\%$ & No. & $\%$ & & & & & & \\
\hline & 118 & 68.6 & 54 & 32.4 & & & & & & \\
\hline
\end{tabular}

By looking closely at the Table (2) above, the following can be observed:

$(50.6 \%)$ of the study sample have five years of practical experience, which indicates that they are fresh graduates and are following the modern programs of artificial intelligence systems.

$(49.4 \%)$ of the study sample had more than five years of experience, during which they practiced - in one way or another - accounting methods and artificial intelligence systems, which leads to confidence in their answers to the questionnaire statements.

(77.90\%) of the study sample hold a bachelor's, master's and doctorate degree, which indicates that most of the sample members have a large degree of scientific qualification that qualifies them to answer the questionnaire objectively.

(93.6\%) of the study sample are specialists in accounting, business administration, financial and banking sciences, and this indicates that the largest proportion of the sample individuals are scientifically and practically knowledgeable in accounting and AI systems, which enables them to answer the questionnaire statements correctly and accurately.

$(68.6 \%)$ of the study sample are males, which are higher than females.This reflects the culture in the Jordanian society in working in the hotel sector. A percentage of $(51.7 \%)$ of the management of the study sample has an independent administration, and a percentage of (18.6\%) has corporate contract companies, and a percentage of (29.7) is smooth $* * *$. 
Description of the answers of the study sample: The answers of the study sample related to the independent variable and the dependent variables can be described by reviewing the arithmetic mean and standard deviations of these answers.

Table No. (3) indicates that the responses of the study sample individuals were positive towards the effect of AI on improving the characteristics of

the quality of accounting information in hotels, (considering that the arithmetic averages of all statements, as can be noted, amounted to (4.1) about "agree"), which means that there is a good level of the use of artificial intelligence in hotels. Furthermore, the values of the arithmetic mean for the phrases of the use of artificial intelligence ranged between (4.26) as the highest value concerning phrase (12) which states that "The procedures for the application of AI systems in the hotel provide means to help

in serving customers while preserving their quality and reliability, "and (3.95) as a minimum value concerning phrase (10) which states that "the procedures for applying artificial intelligence systems in the hotel provide techniques that help reduce material risks, such as the exposure of computer programs and systems to viruses, or software problems. "The relatively low standard deviation of these statements - being less than the (1) - also indicates consistency in the opinions of the sample members about them. 
Table 3. The arithmetic means and standard deviations for answering artificial intelligence expressions as an independent variable.

\begin{tabular}{|c|c|c|c|}
\hline No. & Phrase & $\begin{array}{c}\text { Arithmetic } \\
\text { means }\end{array}$ & $\begin{array}{r}\text { Standard } \\
\text { deviations }\end{array}$ \\
\hline 1 & $\begin{array}{l}\text { Artificial intelligence systems are based on advanced } \\
\text { information systems that contribute to developing } \\
\text { solutions to various problems at the hotel. }\end{array}$ & 4.10 & 0.73 \\
\hline 2 & $\begin{array}{l}\text { When applying AI systems in thehotel, modern } \\
\text { information technologies are used and } \\
\text { the latest software or means of communication are } \\
\text { adopted, especially with regard to the developments } \\
\text { and updates of dealing with the Internet and } \\
\text { websites that have a relationship with the nature of } \\
\text { modern business and areas of dealing with } \\
\text { individuals and companies. }\end{array}$ & 4.17 & 0.72 \\
\hline 3 & $\begin{array}{l}\text { Artificial intelligence systems help managers with the } \\
\text { thinking process, not just provide them with } \\
\text { information }\end{array}$ & 4.10 & 0.94 \\
\hline 4 & $\begin{array}{l}\text { Artificial intelligence applications support } \\
\text { administrators in the strategy and decision-making } \\
\text { process at the hotel. }\end{array}$ & 4.10 & 0.84 \\
\hline 5 & $\begin{array}{l}\text { The use of artificial intelligence systems contributes } \\
\text { to preventing operational errors to reach a high level } \\
\text { of efficiency. }\end{array}$ & 3.96 & 0.94 \\
\hline 6 & 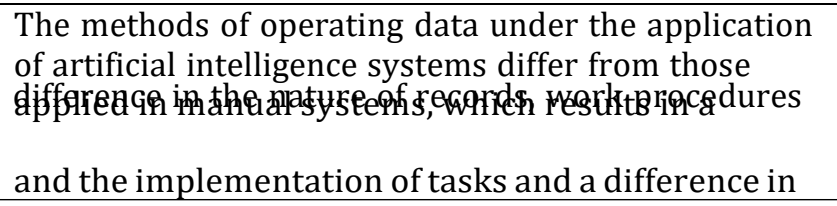 & 4.15 & 0.83 \\
\hline 7 & 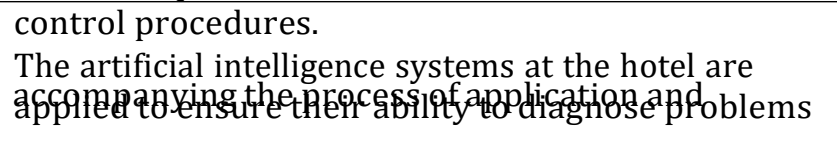 & 3.96 & 0.87 \\
\hline 8 & $\begin{array}{l}\text { procedures for handling. } \\
\text { When applying artificial intelligence systems, the } \\
\text { hotel should have the necessary technology to extract } \\
\text { the data necessary to make decisions. }\end{array}$ & 4.17 & 0.88 \\
\hline 9 & $\begin{array}{l}\text { The procedures for the application of artificial } \\
\text { intelligence systems in the hotel provide a set of } \\
\text { elements for those in charge of applying these } \\
\text { systems to help in providing them with the ability to } \\
\text { enhance the reduction of human risks such as the } \\
\text { lack of professionalism among the users of computer } \\
\text { programs and their operation. }\end{array}$ & 4.01 & 0.81 \\
\hline 10 & $\begin{array}{l}\text { The procedures for applying artificial intelligence } \\
\text { systems in the hotel provide techniques that help in } \\
\text { reducing material risks such as exposure of computer } \\
\text { programs and systems to viruses or programming } \\
\text { problems. }\end{array}$ & 3.95 & 0.96 \\
\hline 11 & 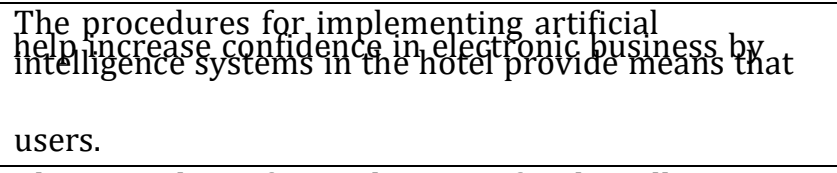 & 4.21 & 0.78 \\
\hline 12 & 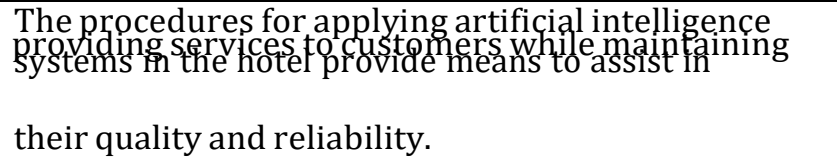 & 4.26 & 0.82 \\
\hline
\end{tabular}


Table 4. The arithmetic means and the standard deviations for answering to expressions as dependent variables.

\begin{tabular}{|c|c|c|c|}
\hline No. Comp. & \multirow{2}{*}{$\begin{array}{l}\text { The Phrase } \\
\text { Accounting systems discover duplicate data } \\
\text { when it is re-entered }\end{array}$} & \multirow{2}{*}{$\begin{array}{l}\begin{array}{l}\text { Arith. } \\
\text { means }\end{array} \\
4.21\end{array}$} & \multirow{2}{*}{$\begin{array}{l}\text { Std. } \\
\text { dev. } \\
0.89\end{array}$} \\
\hline \multirow{8}{*}{ Integration } & & & \\
\hline & $\begin{array}{l}\text { The systems used by programmers are reviewed } \\
\text { to ensure the quality of accounting data } \\
\text { processing }\end{array}$ & 4.20 & 0.76 \\
\hline & $\begin{array}{l}\text { There is flexibility in accounting systems and } \\
\text { their compatibility with the needs and } \\
\text { developments of work in the company }\end{array}$ & 4.28 & 0.70 \\
\hline & $\begin{array}{l}\text { The accounting information systems are linked } \\
\text { with the financial and administrative systems in } \\
\text { the hotel }\end{array}$ & 4.30 & 0.65 \\
\hline & $\begin{array}{l}\text { The software used in operations in accounting } \\
\text { systems provides the possibility of storage for } \\
\text { long periods }\end{array}$ & 4.26 & 0.82 \\
\hline & $\begin{array}{l}\text { The accounting systems are effective and } \\
\text { ensured not to break down }\end{array}$ & 3.83 & 0.99 \\
\hline & $\begin{array}{l}\text { Accounting systems have an adequate level of } \\
\text { security and protection from penetration }\end{array}$ & 4.08 & 0.81 \\
\hline & $\begin{array}{l}\text { The subsystems of the accounting information } \\
\text { system are dependent on each other }\end{array}$ & 4.13 & 0.69 \\
\hline \multirow{6}{*}{ Accuracy } & $\begin{array}{l}\text { The outputs of the accounting systems provide } \\
\text { accurate, complete and reliable information }\end{array}$ & 4.21 & 0.65 \\
\hline & $\begin{array}{l}\text { The outputs of the accounting systems allow the } \\
\text { implementation of new and advanced services } \\
\text { upon request by the hotel management }\end{array}$ & 4.13 & 0.73 \\
\hline & $\begin{array}{l}\text { The reports extracted from the accounting } \\
\text { systems reduce the element of risk }\end{array}$ & 4.03 & 0.82 \\
\hline & $\begin{array}{l}\text { The details found in the financial records } \\
\text { provided by the accounting information system } \\
\text { is capable of checking its accuracy. }\end{array}$ & 4.02 & 0.72 \\
\hline & $\begin{array}{l}\text { The details in the financial records provided by } \\
\text { the accounting information system is objective. }\end{array}$ & 4.07 & 0.75 \\
\hline & $\begin{array}{l}\text { The details in the financial reports provided by } \\
\text { the accounting information system is clear. }\end{array}$ & 4.18 & 0.65 \\
\hline \multirow{6}{*}{$\begin{array}{l}\text { Report } \\
\text { quality }\end{array}$} & $\begin{array}{l}\text { The outputs of accounting systems provide } \\
\text { accountants with information through which to } \\
\text { predict the future }\end{array}$ & 4.13 & 0.43 \\
\hline & $\begin{array}{l}\text { Accounting systems contribute to evaluating the } \\
\text { hotel's financial performance and comparing it } \\
\text { with similar hotels }\end{array}$ & 4.13 & 0.66 \\
\hline & $\begin{array}{l}\text { Accounting systems in the hotel enable } \\
\text { stakeholders to study the financial position, } \\
\text { financial performance and the reality of cash } \\
\text { flows }\end{array}$ & 3.94 & 0.73 \\
\hline & $\begin{array}{l}\text { Accounting system outputs provide accountant } \\
\text { with information that is transparent and clear }\end{array}$ & 3.95 & 0.66 \\
\hline & $\begin{array}{l}\text { The outputs of accounting systems provide } \\
\text { information that can be displayed in the form of } \\
\text { reports and lists according to the accounting } \\
\text { requirements }\end{array}$ & 4.10 & 0.63 \\
\hline & $\begin{array}{l}\text { The outputs of accounting systems provide } \\
\text { information about previous years to study the } \\
\text { trend and conduct financial analysis operations }\end{array}$ & 4.20 & 0.51 \\
\hline
\end{tabular}


By looking at Table (4) above, the following can be observed

The mean values of the phrases of "integration" ranged between (4.30) as the highest value concerning statement (16) which states that "accounting information systems are linked with the financial and administrative systems in the hotel", and (3.83) as the lowest value, concerning phrase (18), which states that "the accounting systems shall be effective and ensured not to break down". The relatively low standard deviation of these statements - being less than the (1) - also indicates consistency in the opinions of the sample members about them.

Similarly, the mean values of the "accuracy" expressions ranged between (4.21) as the highest value pertaining to phrase (21) which states that "the outputs of accounting systems provide accurate, complete and reliable information", and (4.02) as the lowest value pertaining to phrase (24) which states that "the information contained in the financial reports issued by the accounting information system is able to verify its authenticity." The relatively low standard deviation of these statements - being less than (1) - also indicates consistency in the opinions of the sample members about them.

Also, the mean values for the expressions of "report quality" ranged between (4.20) as the highest value pertaining to phrase (32) which states that "the outputs of accounting systems provide information from previous years to study the trend and conduct financial analysis operations", and (3.94) as the lowest value pertaining to the phrase (29), which states that "the accounting systems in the hotel enable the stakeholders to study the financial position, financial performance and the reality of cash flows." The relatively low standard deviation of these statements - being less than (1) - also indicates consistency in the opinions of the sample members about them.

\subsection{Testing Hypotheses}

The researchers used the T-test to examine the main hypothesis which states that "AI systems in Jordanian hotels are not distinguished by efficiency and effectiveness" as the arithmetic mean for applying AI in hotels is approximately 4.095, a value close to the consensus of the study sample, that there is an efficiency and effectiveness of AI systems in hotels which are the study sample, and by looking at table 5 "the T-test", we find that the value of the $\mathrm{P}$ value $=$ 000 at the level of freedom 5\%.Tthis leads to the rejection of the null hypothesis and the acceptance of the alternative hypothesis which states:"AI systems in Jordanian hotels are efficient and effective".

Table 5. The T-test artificial intelligence systems in Jordanian hotels.

\begin{tabular}{ccccccccc}
\hline Upper & Lower & Sig & T & Std error & Std Dev & Mean & N & \\
\hline 4.1838 & 4.0081 & 0.000 & 92.002 & 0.4452 & 0.58388 & 4.0959 & 172 & artint \\
\hline
\end{tabular}

A simple linear regression analysis was used to measure the effect of the independent variable, artificial intelligence, on the dependent variables, and the researchers concluded the following:

There is no statistically significant effect at the level of significance $(\alpha \leq 0.05)$ for the efficiency and effectiveness of artificial intelligence on the integration and interaction of the accounting system in Jordanian hotels. 
Table 6. A simple linear regression analysis model summary.

\begin{tabular}{cccccccccc}
\hline Model & $\mathbf{R}$ & R Square & Adjusted & \multirow{2}{*}{\begin{tabular}{c} 
Std. Error of \\
\cline { 5 - 10 }
\end{tabular}} & & & \multicolumn{5}{c}{ Change Statistics } \\
\cline { 6 - 11 } & & & R Square & the Estimate & R Square Change & F Change & df1 & df2 & Sig. F Change \\
\hline 1 & $0.596^{\mathrm{a}}$ & 0.355 & 0.351 & 0.40488 & 0.355 & 93.513 & 1 & 170 & 0.000 \\
\hline 2 & $0.601^{\mathrm{b}}$ & 0.362 & 0.354 & 0.40389 & 0.007 & 1.831 & 1 & 169 & 0.178 \\
\hline
\end{tabular}

a Predictors: (Constant), artint

b Predictors: (Constant), artint, managtype

${ }^{\mathrm{c}}$ Dependent Variable: integrity

Table 7. The results of a simple linear regression analysis.

\begin{tabular}{ccccccc}
\hline & Model & Sum of Squares & df & Mean Square & F & Sig. \\
\hline \multirow{2}{*}{1} & Regression & 15.329 & 1 & 15.329 & 93.513 & $0.000^{\mathrm{b}}$ \\
\cline { 2 - 7 } & Residual & 27.868 & 170 & 0.164 & & \\
\cline { 2 - 7 } & Total & 43.197 & 171 & & & \\
\hline \multirow{2}{*}{2} & Regression & 15.628 & 2 & 7.814 & 47.901 & $0.000^{\mathrm{C}}$ \\
\cline { 2 - 7 } & Residual & 27.569 & 169 & 0.163 & & \\
\hline & Total & 43.197 & 171 & & & \\
\hline
\end{tabular}

\footnotetext{
a Dependent Variable: integrity

b Predictors: (Constant), artint

c Predictors: (Constant), artint, managtype
}

Table 6 below shows the results of a simple linear regression analysis of the effect of AI applied in Jordanian hotels on the integration of accounting information systems, and that the correlation between artificial intelligence and integration of accounting information systems is $(\mathrm{R}=59.6 \%)$, and that the percentage is explained by the application of applied AI in Jordanian hotels where

(R2) reached (35.5\%) of the variance of the dependent variable (accounting information systems integration). It also shows that the fixed limit value amounted to (2.060), and that the value of (Beta) for the independent variable "AI" applied in the accounting systems in Jordanian hotels reached (0.596).

The following table shows the results of a simple linear regression analysis of the artificial intelligence relationship applied in Jordanian hotels, that the percentage of what is explained by the application of AI (R2) amounted to (446\%) of the variance of the dependent variable

(information accuracy), which is a good interpretation ratio, and that the value of the constant term It reached (1.664) and that the (Beta) value for the independent variable amounted to (0.688) and the (Beta) value for the intermediate variable Management Type (0.054) It is noticeable that the (Beta) value for the intermediate variable is negative reflexing the relationship between management type and accuracy in information systems. Accounting applied to hotels Based on the above results of the analysis, it leads us to reject the null hypothesis and accept the alternative hypothesis.

The following table shows the results of a simple linear regression analysis of the artificial intelligence relationship applied in Jordanian hotels, that the percentage of what is explained by the application of artificial intelligence (R2) amounted to (389\%) of the variance of the dependent variable (the quality of reports), which is a good interpretation ratio, and that the value of the fixed limit It reached (1.664) and that the (Beta) value for the independent variable amounted to (.386) and the (Beta) value for the intermediate variable Management type (-.054-). It is noticeable that the (Beta) value for the intermediate variable is negative reflecting the relationship between the type of management and the quality of reports in Accounting information systems applied in hotels. Based on the above results of the analysis, it leads us to reject the null hypothesis and accept the alternative hypothesis. 
Table 8. Simple linear regression analysis of the effect of "artificial intelligence" applied in Jordanian hotels on the integration of accounting information systems.

\begin{tabular}{cccccccccc}
\hline R & R Square & Adjusted & F & Sig $^{*}$ & \multicolumn{5}{c}{ Regression coefficients } \\
\cline { 6 - 9 } & & & & \multicolumn{2}{c}{ Domain } & $\beta$ & Std. Error & T & Sig* \\
\hline 0.596 & 0.355 & 0.351 & 93.51 & $0.00^{*}$ & Artificial Intelligence & 0.596 & 0.053 & 9.670 & $0.000^{*}$ \\
\hline
\end{tabular}

Based on the above results of the analysis,we reject the null hypothesis and accept the alternative one; there is a statistically significant effect at the level of $(\alpha \leq 0.05)$ for the efficiency and effectiveness of artificial intelligence on the integration and interdependence of the accounting system in Jordanian hotels. The simple regression equation is formulated.

\section{Conclusions}

The following table shows the results of a simple linear regression analysis of the artificial intelligence relationship applied in Jordanian hotels, that the percentage of what is explained by the application of artificial intelligence (R2) amounted to (389\%) of the variance of the dependent variable (the quality of reports), which is a good interpretation ratio, and that the value of the fixed limit It reached (1.664) and that the (Beta) value for the independent variable amounted to (.386) and the (Beta) value for the intermediate variable Management type (-.054-). It is noticeable that the (Beta) value for the intermediate variable is negative reflecting the relationship between the type of management and the quality of reports in Accounting information systems applied in hotels It is noteworthy that the accounting system tended to be an information system that does not stop at the limits of financial data and information, but rather to include quantitative and descriptive data and information that benefit the decision-makers and users who are distinguished by multiplicity and diversity. Appropriate in a timely manner and increase the assurance of external information for planning deviation and amend reports submitted to management under the design. As a result, the accounting information system has become to provide additional information along with financial information as data and quantitative and financial information with appropriate accuracy, quality, in a timely manner, as well as to increase the assurance of external information for deviation of planning and amendment of reports submitted to management under the design. The accounting information system is one of the subsystems in the economic entity that work with each other in a connected, coherent and interchangeable manner with the aim of providing historical, current and future, financial and non-financial information to all entities concerned with the matter of the economic union in a manner that serves the achievement of its objectives.

Meanwhile, all hospitality companies in the business world and the global economy are dealing with issues of technology for survival, as AI would be a suitable solution to this problem. A global survey in AI [54] predicted "an increase of more than 300\% in investment in artificial intelligence in 2017 compared to 2016" as evidence of the rapid global growth in the banking and services sector.

The world started increasing the interest in the development of the communications and information technology sector. AI helps the human mind within the organizations developed by technology, and it helped institutions improve the circulation of data and information between their various units [55-57].

AI works on rapprochement with human intelligence through computer programs that keep pace with human behavior. These programs are characterized by intelligence, speed of electronically processing operations, and providing users with the data and information they need in various decisions very quickly.

Artificial intelligence now has the ability to determine the best possible way to get an appropriate answer; it can also use routine operations that give the best results, in addition to downloading documents automatically, evaluating the input data, and classifying it according to advanced accounting systems. Artificial intelligence is free from errors, does not feel tired, and does not know fatigue.

In the public sector, contemporary technical applications are commonly used; robotics and AI have long been adopted by the transport, law enforcement, armed forces, and health care industries. Through digital transformation, our daily lives have been influenced and, as such, this change has also affected the 
hospitality industry.

\section{References}

1. Prentice, C.; Dominique Lopes, S.; Wang, X. The impact of artificial intelligence and employee service quality on customer satisfaction and loyalty. Journal of Hospitality Marketing $\mathcal{E}$ Management 2020, 29, 739-756.

2. Millauer, T.; Vellekoop, M. Artificial intelligence in today's hotel revenue management: opportunities and risks. Research in Hospitality Management 2019, 9, 121-124.

3. Branch, J. THE INFLUENCE OF TRAVELER REVIEWS ON MOBILE APPLICATIONS ON TRAVEL DECISION-MAKING TO DUBAI. Journal of Theoretical and Applied Information Technology 2020, 98.

4. Wang, X.L. The impact of revenue management on hotel key account relationship development. International Journal of Contemporary Hospitality Management 2012, 24, 358-380.

5. Cavusoglu, M. An analysis of technology applications in the restaurant industry. Journal of Hospitality and Tourism Technology 2019, 10, 45-72.

6. Li, J.; Xu, L.; Tang, L.; Wang, S.; Li, L. Big data in tourism research: A literature review. Tourism Management 2018, 68, 301-323.

7. Naumov, N. The impact of robots, artificial intelligence, and service automation on service quality and service experience in hospitality; Emerald Publishing Limited, 2019.

8. Hill, J.; Ford, W.R.; Farreras, I.G. Real conversations with artificial intelligence: A comparison between human-human online conversations and human-chatbot conversations. Computers in human behavior 2015, 49, 245-250.

9. Askary, S.; Abu-Ghazaleh, N.; Tahat, Y.A. Artificial intelligence and reliability of accounting information. Conference oneBusiness, e-Services and e-Society. Springer, 2018, pp. 315-324.

10. Gartner, G. Hype Cycle for Emerging Technologies Identifies Three Key Trends That Organizations Must Track to Gain Competitive Advantage, Gartner's 2016 Hype Cycles Highlight Digit. Bus. Ecosyst.(2016) 2016, 1, 90018-3.

11. JAWABREH, O. INNOVATION MANAGEMENT IN HOTELS INDUSTRY IN AQABA SPECIAL ECONOMIC ZONE AUTHORITY; HOTEL CLASSIFICATION AND ADMINISTRATION AS A MODERATOR. GeoJournal of Tourism and Geosites 2020, 32, 1362-1369.

12. Cengiz, E.; Cengiz, F.; Cavusoglu, M.; Cobanoglu, C. Managerial perceptions of cost-system obsolescence and factors that might affect it. International Journal of Contemporary Hospitality Management 2019, 31, 2884-2913.

13. Potter, G.S.; Schmidgall, R.S. Hospitality management accounting: current problems and future opportunities 1999. 18, 387-400.

14. Yeager, V.A.; Zhang, Y.; Diana, M.L. Analyzing determinants of hospitals' accountable care organizations participation: A resource dependency theory perspective. Medical Care Research and Review 2015, 72, 687-706.

15. Kajraman, C.; Kahraman, C.; Kaya, I .; Çevikcan, E. Intelligence decision systems in enterprise information management. Journal of Enterprise Information Management 2011, 24, 360-379.

16. Martínez-de Pisón, F.J.; Pernía, A.V.; Blanco, J.; Gonzalez, A.; Lostado, R. Control model for an elastomer extrusion process obtained via a comparative analysis of data mining and artificial intelligence techniques. Polymer-Plastics Technology and Engineering 2010, 49, 779-790.

17. Schank, R.C.; Slade, S.B. The future of artificial intelligence: learning from experience. Applied Artificial Intelligence an International Journal 1991, 5, 97-107.

18. Schulze-Horn, I.; Hueren, S.; Scheffler, P.; Schiele, H. Artificial Intelligence in Purchasing: Facilitating Mechanism Design-based Negotiations. Applied Artificial Intelligence 2020, 34, 618-642.

19. Shrivastava, R.; Mahajan, P. Artificial intelligence research in India: A scientometric analysis. Science E Technology Libraries 2016, $35,136-151$.

20. Wu, H.; Gu, X.; Zhao, Y.; Liu, W. Research on the Relationship between Structural Hole Location, Knowledge Management and Cooperative Innovation Performance in Artificial Intelligence. Knowledge Management Research E Practice 2020, pp. 1-10.

21. Wang, Y.; Skeete, J.P.; Owusu, G. Understanding the implications of artificial intelligence on field service operations: a case study of BT. Production Planning E Control 2021, pp. 1-17.

22. Wamba-Taguimdje, S.L.; Wamba, S.F.; Kamdjoug, J.R.K.; Wanko, C.E.T. Influence of artificial intelligence (AI) on firm performance: the business value of AI-based transformation projects. Business Process Management Journal 2020.

23. Kietzmann, T.C.; McClure, P.; Kriegeskorte, N. Deep neural networks in computational neuroscience. In Oxford research encyclopedia of neuroscience; 2019.

24. Vrontis, D.; Christofi, M.; Pereira, V.; Tarba, S.; Makrides, A.; Trichina, E. Artificial intelligence, robotics, advanced technologies and human resource management: a systematic review. The International Journal of Human Resource Management 2021, pp. 1-30.

25. Baldwin-Morgan, A.A. Integrating artificial intelligence into the accounting curriculum. Accounting education 1995, 4, 217-229.

26. Damerji, H.; Salimi, A. Mediating effect of use perceptions on technology readiness and adoption of artificial intelligence in accounting. Accounting Education 2021, pp. 1-24.

27. Geist, E.M. (Automated) planning for tomorrow: Will artificial intelligence get smarter? Bulletin of the Atomic Scientists 2017, $73,80-85$.

28. Ha, T.; Sah, Y.J.; Park, Y.; Lee, S. Examining the effects of power status of an explainable artificial intelligence system on users' perceptions. Behaviour E Information Technology 2020, pp. 1-13.

29. Kerzel, U. Enterprise AI Canvas Integrating Artificial Intelligence into Business. Applied Artificial Intelligence 2021, 35, 1-12. 
30. Malone, D. Expert systems, artificial intelligence, and accounting. Journal of Education for Business 1993, 68, 222-226.

31. Kumar, S. Artificial intelligence divulges effective tactics of top management institutes of India. Benchmarking: An International Journal 2019, 26, 2188-2204.

32. Paschen, J.; Kietzmann, J.; Kietzmann, T.C. Artificial intelligence (AI) and its implications for market knowledge in B2B marketing. Journal of Business \& Industrial Marketing 2019, 34, 1410-1419.

33. Granlund, M. Management accounting system integration in corporate mergers. Accounting, Auditing E Accountability Journal 2003, 16, 208-243.

34. Hendricks, K.B.; Singhal, V.R. Firm characteristics, total quality management, and financial performance. Journal of operations management 2001, 19, 269-285.

35. Grossi, G.; Kallio, K.M.; Sargiacomo, M.; Skoog, M. Accounting, performance management systems and accountability changes in knowledge-intensive public organizations. Accounting, Auditing $\mathcal{E}$ Accountability Journal 2019, 33, $256-280$.

36. Jang, S.; Tang, C.H.; Park, K.; Hsu, L.T. Research Note: The Marketing—Finance Interface-A New Direction for Tourism and Hospitality Management. Tourism Economics 2013, 19, 1197-1206.

37. Loft, A. The history of management accounting: relevance found; Prentice Hall, 1995.

38. Park, K.; Jang, S.S. Hospitality finance and managerial accounting research. International Journal of Contemporary Hospitality Management 2014, 26, 751-777.

39. Winata, L.; Mia, L. Information technology and the performance effect of managers' participation in budgeting: evidence from the hotel industry. International Journal of Hospitality Management 2005, 24, 21-39.

40. de Koning, W.F. The Quality of Accounting Information. Available at SSRN 23247792013.

41. Maria do Céu, F. Management accounting and information technology-some empirical evidence. In Performance Measurement and Management Control: Innovative Concepts and Practices Studies in Managerial and Financial Accounting; Emerald Group Publishing Limited, 2010; Vol. 20, pp. 429-455.

42. Ogbeide, G.C.; Fu, Y.Y.; Cecil, A.K. Are hospitality/tourism curricula ready for big data? Journal of Hospitality and Tourism Technology 2020.

43. Wessels, P. Information technology and the education of professional accountants. Meditari Accountancy Research 2004, 12, 219-234

44. Saleh, M.M.A.; Jawabreh, O.A. Role of environmental awareness in the application of environmental accounting disclosure In tourism and hotel companies and its impact on Investor's decisions in Amman Stock Exchange. International Journal of Energy Economics and Policy 2020, 10, 417.

45. Ahmed, A. The level of IT/IS skills in accounting programmes in British universities. Management research news 2003, $26,20-58$.

46. Brookfield, D. Risk and organizational effectiveness: The role of accounting systems as a managerial process. Journal of Organizational Effectiveness: People and Performance 2018, 5, 110-123.

47. Barth, M.E.; Landsman, W.R.; Lang, M.H. International accounting standards and accounting quality. Journal of accounting research 2008, 46, 467-498.

48. Dufour, D.; Luu, P.; Teller, P. Accruals quality and leverage adjustments. Journal of Applied Accounting Research 2020.

49. Nalukenge, I.; Nkundabanyanga, S.K.; Tauringana, V. Literacy, External User-Pressure and Quality of Accounting Information of Ugandan SMEs. In Accounting in Africa; Emerald Group Publishing Limited, 2012.

50. Paulo, E.; Martins, E.; Girão, L.F.d.A.P. Accounting information quality in Latin-and North-American public firms. In Accounting in Latin America; Emerald Group Publishing Limited, 2014.

51. Watts, R.L. Conservatism in accounting-part II: evidence and research opportunities. Available at SSRN 438662 2003, 17, 287-301.

52. Xu, H.; Nord, J.H.; Nord, G.D.; Lin, B. Key issues of accounting information quality management: Australian case studies. Industrial Management \& Data Systems 2003, 103, 461-470.

53. Wirtz, B.W.; Weyerer, J.C.; Geyer, C. Artificial intelligence and the public sector-Applications and challenges. International Journal of Public Administration 2019, 42, 596-615.

54. Alazzam, M. Theories and factors applied in investigating the user acceptance towards personal health records: Review study Theories and factors applied in investigating the user acceptance towards personal health records: Review study. Int J Healthc Manag [Internet] 2017, pp. 1-8.

55. Hamadneh, NN. Dead Sea Water Levels Analysis Using Artificial Neural Networks and Firefly Algorithm. International Journal of Swarm Intelligence Research (IJSIR) 2020,11: 19-29.

56. Rashedi, KA;Ismail MT;Hamadneh NN;Wadi S;Jaber JJ, et al. Application of Radial Basis Function Neural Network Coupling Particle Swarm Optimization Algorithm to Classification of Saudi Arabia Stock Returns. Journal of Mathematics 2021,PP.1-8.

57. Hamadneh, NN;Tahir M, Khan WA. Using artificial neural network with prey predator algorithm for prediction of the COVID-19: the case of Brazil and Mexico. Mathematics 2021,9: 180. 